\title{
Upgrading Export Structure In Sub-Saharan Africa
}

Marcel Kohler, University of KwaZulu-Natal, South Africa

Thembeka Khumalo, University of KwaZulu-Natal, South Africa

\begin{abstract}
A major focus of research on trade policy reform relates to whether changes in global economic participation, brought about by such reform, provides for sustainable income growth in the countries concerned. The challenge for many African economies in this context is to improve their position in the global economy by upgrading their export structures. The authors' empirical work suggests that export diversification is a critical first step in upgrading export structure in SubSaharan African (SSA) countries. The authors find that the knowledge gained from the export diversification process, along with technology spillovers associated with FDI flows, are important drivers. Furthermore, they find evidence of learning by doing productivity gains from SSA exporting activity. On the whole, the authors do not find that the rise of Asian driver economies poses a significant threat to SSA export sophistication. What is crucial to the further success of SSA countries' upgrading their export structure is government policy initiatives that prioritise the upgrading of infrastructure, human capital development and institutional reform. These efforts will ensure that SSA countries can realise real economic gains through improvements in their export structures rather than locking their economies into commodity dependence on the basis of their favourable natural resource endowments.
\end{abstract}

Keywords: Export Diversification; Export Sophistication; Sub-Saharan Africa

\section{INTRODUCTION}

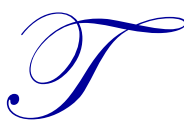

he global economy provides an opportunity for less developed countries to participate in export markets, improve productivity, industrialise, and grow national incomes. Institutions, such as the World Trade Organisation (WTO), the International Monetary Fund (IMF), and the World Bank (WB), identify such opportunities as the main motivation behind the trade liberalisation policy prescription for such countries.

Although the last few decades have seen major growth in world trade, the benefits of globalisation have not been evenly distributed across the developing world. Developing countries in Asia have seen the highest trade growth and witnessed the greatest associated economic benefits. Whilst developing countries in Africa have also seen some level of trade volume growth on the whole, the dynamic gains associated with trade liberalization, particularly in as far as productivity improvements, technological catch-up and industrialization, have been insignificant for most of these African economies.

Popular theories put forward to explain the trade success differences of these two groups of countries draw mostly on aspects of the "resource curse" argument which suggests that countries that are well endowed with natural resources, like many in Africa, tend to underperform in terms of economic growth. This is due to the tendency of these countries to specialise in resource-intensive exports. These commodity exports have historically been subject to numerous drawbacks, including declining terms of trade, low rates of investment, low rates of human capital accumulation and low productivity growth \& technology spill-overs. Sub Saharan African economies, many of whom are commodity dependent exporters, have registered dismal growth rates. On the other hand, developing countries, particularly those in Asia with insignificant resource endowments, have managed to harness economic growth through the production and trade of manufactured goods. The "resource curse" argument thus suggests that 
the structure of exports has a significant impact on countries' economic growth. The economic growth of countries that focus their resources in low technology-intensive exports is lower than for those specialising in the production of high value-added technology-intensive goods for export. This is consistent with the view by Rodrick (2006) that the economic growth success of a country relates back to the value of the goods the country produces.

What is clear is that it is not mere participation in the global economy through a country's trade liberalisation efforts that matters but whether the manner of participation allows for sustainable income growth (Kaplinsky, 2004). The challenge, therefore, for many African economies is to improve their position in the global economy by upgrading their export structures. This requires them to diversify their economies by initially producing a variety of higher value-added exports and following on from this moving into the production of technologyintensive exports in the long run. The upgrading of export structures requires an improvement in the technological capacity within these countries to help facilitate the start-up of competitive manufacturing industries, thereby enabling them to absorb external technological spill-overs. Given the low technology base and low level of research and development in African economies in general, most of the technological advancement within these countries will be through technology that is acquired and adapted through trade and foreign direct investment (FDI) flows from developed country counter parts. What is imperative, therefore, is that the technological absorptive capacity of African countries be improved in order to help them realise the greatest possible gains from foreign trade and FDI.

Section 2 reviews the literature on the determinants of export sophistication and diversification; Section 3 presents the model specification, methodology and data sources used in this study; Section 4 presents the empirical results; and Section 5 contains the concluding remarks.

\section{THE DETERMINANTS OF EXPORT SOPHISTICATION AND DIVERSIFICATION}

The literature on the subject of trade structure determinants is rich in both diversity of theories offered and empirical analyses observed. Traditional trade theory suggests that a country's pattern of trade is largely determined by its resource endowments, including, amongst others, labour, physical capital, natural resources, human capital, and institutional quality. Acemoglu \& Zilibotti (1997) share this traditional view, emphasising the role of fundamentals such as resource endowments. In particular, they argue that a country's trade and export diversification opportunities are limited at lower levels of economic development due to scarcity of capital and indivisibility of investment opportunities. Economic development encompasses a wide range of characteristics, including human and physical capital accumulation, institutional development, and economic structure. In this context, Acemoglu \& Zilibotti (1997) suggest that less-developed countries are expected to have highly concentrated, less sophisticated export structures. Hausman et al. (2007) argue that while resource endowments are important, other explanatory factors, such as technology spillovers from trade and foreign direct investment, play a significant role in determining a country's export structure. Habiyaremnye \& Ziesemar (2008) consider the importance of absorptive capacity in determining export diversification. Wang and Wei (2007), taking into account the "Dutch Disease" hypothesis, consider economic structure as an additional determinant. This suggests that export sophistication ${ }^{1}$ can be explained by traditional determinants, as well as the scope for technological spill-overs, technological absorptive capacity and economic structure. The same can be said for the determinants of export diversification ${ }^{2}$.

Hausman et al. (2007) suggest that a sophisticated export structure is associated with a dominance of "rich country", higher value export goods. Therefore, the export sophistication of a country should be correlated with income, as proxied by per capita GDP, with wealthier countries achieving higher levels of export sophistication. Given that per capita GDP is an accepted measure of development, the link between development and export structure suggested by Acemoglu \& Zilibotti (1997) further indicates that per capita GDP affects export structure. Empirical investigations of the determinants of export sophistication and diversification, such as Hausman et al. (2007), Parteka and Tamberi (2008), Schott (2008), Fu et al. (2009), Cabral and Viega (2010), and Weldemicael (2010) find evidence of a positive relationship between per capita GDP and export sophistication as well as export diversification.

\footnotetext{
${ }^{1}$ Refers to the skill and technological intensity in an export basket.

${ }^{2}$ Refers to the variety in an export basket.
} 
The theorised "resource curse" argument suggests that poorer economic performance is associated with countries with better natural resource endowments. In particular, the tendency of economic activity in resource-rich economies to be concentrated in the primary sector, rather than in the manufacturing sector, limits learning-by-doing externalities which then constrains industrial development and manufacturing activity in these countries. In this manner, resource endowments constrain opportunities for technological development and thereby perpetuate a country's inferior export structure. Strong evidence in support of the resource curse argument has been found, particularly in less-developed economies with weak institutional and development capabilities. Hausman et al., 2007; Fu et.al, 2009; Habiyaremye and Ziesemer, 2006; and Bebczuk and Berrettoni, 2006 all confirm a negative association between a country's natural resource endowment, the extent of its export sophistication and the level of its export diversification.

New trade theories contribute to the discussion through recognising the role and significance of market size in influencing the extent of product differentiation in a country's exports (Dixit and Norman, 1980; Helpman and Krugman, 1985). Studies by Hausman et al. (2007), Parteka \& Tamberi (2008), Fu et al. (2009), Weldemicael (2010), Cabral and Viega (2010) all find evidence in support of the notion that larger economies are associated with more sophisticated and diversified export structures due to economies of scale and a broader range of available skills. In contrast, Habiyaremye \& Ziesemer (2006) find no evidence that population size is significant when estimating the determinants of export diversification in SSA, suggesting a uniform distribution of skills and economic activities across population groups in the region.

The roles of both domestic and foreign sources of knowledge on economic growth and development are highlighted in the new growth literature by Romer (1990). Habiyaremye \& Ziesemer (2006) identify three channels through which domestic knowledge capital, proxied by measures of educational attainment, impact on economic development. Firstly, education increases labour productivity. Secondly, highly skilled, educated workers allow the economy to produce more sophisticated goods and facilitate technology upgrading. Thirdly, an educated and skilled labour force is associated with the development of new technologies and the effective absorption of technological spillovers. The empirical evidence on the impact of education on export structure is varied. Hausmann et al. (2007), Wang \& Wei (2007), and Fu et al. (2009) conclude that educational attainment improves export sophistication, while Weldemichael (2010) finds tertiary educational attainment to be an insignificant determinant of export sophistication. Habiyaremye \& Ziesemar (2006) find that while it is important for SSA countries, educational attainment levels have no impact on the extent of export diversification of non-SSA countries. Similarly, Parteka and Tamberi (2008) find that human capital has no impact on export diversification, since this captures the variety of products in a country's export basket rather than specifically the skill or technology intensiveness of these products. This seems to suggest that educational attainment may instead be more important in determining the export sophistication of a country, as this is closely associated with the level of skill and technology intensiveness of goods in production.

Sources of foreign knowledge capital include foreign direct investment (FDI) and trade flows between countries. These sources of technology spill-overs are important for developing economies with weak domestic technological development capabilities. In particular, technological spill-overs aid the development of industrial technology in related domestic industries (Coe \& Helpman, 1995). FDI impacts on the export composition of a host nation in both a direct and indirect manner. It directly affects export composition if it increases exports of manufactured goods. For example, capital required in manufacturing production can be obtained through FDI, whilst the potential for technology spill-overs is an additional, indirect benefit associated with FDI. Borensztein et al. $(1998)^{3}$ was one of the first to empirically attempt to validate this notion by finding that the environment in the host country plays a significant role as a determinant of diffusion of technology spill-overs. Ernst \& Kim (2002) agree that local capabilities in assimilating, adapting and improving important technology are associated with technology spill-overs. In other words, technology absorptive capacity in the host country determines the extent of spill-overs from FDI. Technology absorptive capacity encompasses the quality of human capital, infrastructure, financial development, and institutions (Lall, 2000). Borensztein et al. (1998) argue that it is human capital that determines the ability of a country to adopt foreign technology. Noorbukhsh et al. (2001), Sanchez-Robles (2003), Durham (2004), and Li \& Lui (2005) also find empirical evidence that human capital is essential for FDI technology spill-

\footnotetext{
${ }^{3}$ See also Carkovic and Levine (2002); Le Vu and Suruga (2005).
} 
overs. This paper adds to the empirical literature on the determinants of export structure by considering the impact of the interactions between human capital and FDI and infrastructure and FDI on export structure.

Imports are also sources of foreign knowledge capital and the importation of intermediate goods directly impacts on the technology content of domestic output. Some countries, particularly China and other Asian countries, export technology-intensive products not because of capability, but through the assembly of high technology intermediate imports (Xu, 2007). The opportunity to imitate and reverse-engineer imported goods adds a potential indirect spill-over benefit from imports. In comparison with FDI spill-overs, import spill-overs are found to be less important. Fu et al. (2009) find empirical evidence confirming that imports do improve export sophistication. In developing economies, imports may pose a competitive threat to domestic manufacturing firms. If domestic firms are unable to compete in terms of price or quality, manufacturing activity will decline which could lead to deindustrialisation.

The exportation of goods exposes domestic firms to broader and more advanced markets with higher requirements of quality. This necessitates, and therefore generates, higher levels of productivity within these firms. Domestic industry is also impacted through backward linkages between foreign buyers and domestic suppliers. Blalock \& Gertler (2004) find evidence of learning from exporting, which has raised productivity in Indonesian manufacturing firms. Similarly, in a study of nine African countries, Biesebroek (2005) finds evidence that exporters become more productive after they enter export markets. A larger share of manufactured exports in total exports improves its structure. Manufacturing activity has higher potential for technology spill-overs for the wider economy, which should aid diversification. Bebzcuk \& Berrettoni (2006) confirm this by finding that manufactured exports do improve export diversification. In particular, it is found that a diversified export structure provides a base for technological upgrading, improving export sophistication in the long run.

Another important issue that is found to be associated with economic performance and a country's specialisation patterns is institutional quality. A theoretical framework developed by Krishna \& Levcheriko (2009) shows that openness to international trade pushes less-developed countries, with lower institutional ability, to specialise in less-complex goods. Complex goods are those that require high-skill human capital, advanced technology, and well-organised production systems. (Levchenko, 2004) finds that institutional differences are a significant determinant of the share of trade in complex products. While various measures of institutional quality are used in the empirical literature, generally indicators of government effectiveness are favoured. Weldemichael (2010) finds that economic freedom, as a measure of institutional quality, improves export sophistication. Fu et al. (2009), using a rule of law index, find no association between institutional quality and export sophistication. Parteka \& Tamberi (2008) find that amongst the numerous measures of institutional quality considered only the freedom to trade index has an impact on export diversification. The lack of consensus in the empirical literature is largely due to the use of various different measures of institutional quality.

There exists a small body of literature that suggests that the rise of Asian economies may pose a threat to export-led industrialisation in SSA. Qureshi \& Wan (2006) group the impacts of the growth of the AD's into three effects:

(i) Complementary effect - The effect of a growth in exports to AD's as a result of an increase in demand in the AD's.

(ii) International competitiveness effect - The increase in competition from the exports of AD's in third markets.

(iii) Domestic competitiveness effect - The increase in competition from AD's imports in the domestic market.

The complementary effect suggests that growth in $\mathrm{AD}$ economies, which is accompanied by an increase in the demand for resource exports from SSA, will induce SSA to re-specialise in commodity exports. Eichengreen et al. (2004) investigate the impact of the rise of China on its neighbours and conclude that countries producing raw materials that are used intensively in Chinese manufacturing may specialise further into these commodities. Gabe (2006) refers to this outcome as the 'primary sector locking effect' which would result in SSA deepening its specialisation in commodities, affecting export diversification, sophistication, and industrialisation. The most significant consequence of this for industrialisation is that technological development, which is essential for the 
growth of the manufacturing sector, is limited. Jenkins \& Peters (2006) refer to this phenomenon as the deindustrialisation of SSA, which may be particularly disastrous for the region where industrialisation is still in early stages of development.

An additional threat posed by the rise of the Asian Drivers on SSA's export performance is a direct competitive effect in third markets. Steven \& Kannan (2006) predict that countries that export similar goods to Asian Drivers, especially manufactures, will suffer a fall in export demand. China's competitive advantage lies in its relatively cheap, abundant labour and undervalued currency. Kaplinsky (2008) predicts that labour costs in China will remain fairly stable in the near future due to the significant labour reserve in the country's rural regions. This may result in other developing countries struggling to compete in manufactures for some time.

The final and least discussed threat in economic literature is that of cheap imports which can be both a threat and an opportunity for further industrialisation in SSA. Importation of cheap intermediate inputs results in falling production costs for domestic firms, enabling them to produce more competitively for the export market. Imports of finished goods, however, will compete with local industries that may still be in their earlier stages of development and require some level of insulation from competition until they are price and quality competitive. If cheap imports are able to displace local producers, then growth of the manufacturing sector, which is essential to industrialisation, will be reduced. The authors will test for the effect of the rise of AD's on the export structure of SSA.

\section{MODEL SPECIFICATION, METHODOLOGY AND DATA}

\subsection{Model Specification}

The empirical model specification was constructed with formulae extracted from the theoretical literature on the determinants of modern sector productivity. The choice of variables is guided by previous research on the determinants of export sophistication and export diversification. This study aims to build on the model of Cabral \& Viega (2010), which estimates the determinants of export sophistication and diversification in SSA. Their model fails to take into account the influence of technology spill-overs, infrastructure, and the interactions between domestic absorptive capacity and technology spill-overs.

Hausman, et al. (2007) developed a theoretical framework of the determinants of modern sector productivity. It is assumed that the economy consists of two sectors - one being a traditional sector and the other a modern sector. The distinction between the two sectors is the level of productivity and technology employed in each. The traditional sector is the simpler one producing unsophisticated goods for domestic consumption, whilst the modern sector produces a higher variety of value-added and technology-intensive goods. Inputs of the modern sector include the traditional inputs of labour, capital, and natural resources. The Cobb-Douglas production function of the modern sector is given by:

$$
Y=A L^{\alpha} K^{\beta} R^{\gamma}
$$

There are constant returns to scale, specifically the coefficients $\alpha+\beta+\gamma=1$. The letters $K, L, R$ represent physical capital, labour and natural resources, respectively. A represents technological progress, distributed over the rage $[0, \hat{A}]$, which is sourced both domestically and from foreign sources. Thus:

$$
\hat{A}=B D^{\sigma_{D}} F^{\sigma_{F}} I^{\sigma_{I}}
$$

Â is a function of a constant $(B)$, domestic $(D)$ and foreign $(F)$ sources of knowledge, and the capability to reap the benefits of both kinds of knowledge $(I)$. The capability to benefit from domestic and foreign sources of knowledge is determined by the level of absorptive capacity, which includes the quality of human capital, financial development and institutional quality. Therefore, the greater the value of Â., the more capacity an economy has to produce goods of higher productivity. 
Substituting (2) into (1) results in the following expression for expected output:

$$
E(Y)=B D^{\sigma_{D}} F^{\sigma_{F}} I^{\sigma_{I}} L^{\alpha} K^{\beta} R^{\gamma}
$$

With constant returns to scale, the expected labour productivity is expressed as:

$$
E(Y) / L=B D^{\sigma_{D}} F^{\sigma_{F}} I^{\sigma_{I}}(K / L)^{\beta}(R / L)^{\gamma}
$$

Equation (4) suggests that the productivity of the modern sector is a function of the capital-labour ratio and per capita natural resource endowments, domestic and foreign knowledge capital, and the ability to benefit from both kinds of knowledge sources.

Assuming the modern sector to be the export sector, $E(Y) / L$ can be proxied by an export sophistication index (EXPY), the productivity level of a country's export basket. Assuming that a more productive export sector would not only be more manufactured goods based, but also more diversified, the determinants of export diversification should be similar to those of sophistication. $E(Y) / L$ can also be proxied by the diversification index (relTheil).

Considering the previous literature on the determinants of export sophistication and diversification, as discussed in Section 2, together with the theoretical model of export sector productivity discussed above, the econometric specification is:

$$
\begin{gathered}
\log \left(\text { EXPY }_{i t} / \text { relTheil }_{i t}\right)=\alpha+\gamma_{x} \log \left(Z_{i t}\right)+\beta_{1} F D I_{i t}+\beta_{2} \text { Imp }_{i t}+\beta_{3} \text { ManufExp }_{i t}+\beta_{4} \log \left(\text { Herf }_{i t}\right) \\
+\beta_{5} \log \left(\text { Elect }_{i t}\right)+V_{i t}+U_{i t}+\varepsilon_{i t}
\end{gathered}
$$

where $Z_{i t}$ includes control variables - capital-labour ratio (Capl), GDP per capita (Y), population (Popl), land per capita (Landp), primary school enrolment ratio (Educp), and Institutional Quality proxied by an index of political stability (GovtP). FDI and Imp are the proportions of foreign direct investment (inflows) and imports to GDP, respectively. ManufExp is the proportion of manufactured exports in total exports. Herf is the herfindahl index, a measure of export diversification; Elect is the total consumption of electricity; $V_{i t}$ indicates country fixed effects; $U_{i t}$ year dummies; and $\varepsilon_{i t}$ is a random error term.

\subsection{Estimation Method}

The model is estimated by ordinary least squares (OLS), controlling for country and time effects. Models are estimated with robust standard errors to eliminate possible heteroscedasticity and autocorrelation of the panel data. An endogeneity concern arises between FDI and EXPY. Economic literature finds significant endogeneity between foreign direct investment and technological progress (Li \& Liu, 2005). Foreign direct investment is expected to have a positive effect on export sophistication; however, countries with sophisticated export structures are expected to attract more FDI. If FDI is endogenous, then the OLS estimation will be invalid. To account for possible endogeneity, the authors also estimate the model by 2SLS instrumental variables (IV) method. The major problem with the IV estimation method is the difficulty in identifying instruments that are highly correlated with FDI but not with the error term. Makki (2004) uses a lag of FDI and a log of GDP as instruments for FDI. Fu et al. (2009) also use a lag of FDI together with a measure of infrastructure and financial development as instruments. The authors choose not to use infrastructure and financial development as instruments as the authors would like to estimate their direct effect on export structure by including them in the base model. The authors thus choose to use a lag of FDI and a $\log$ of GDP as instruments for FDI. The authors test for the endogeneity of FDI by employing the Durbin-Wu-Hansen test (Cameron \& Trivedi, 2009). The authors then test for the validity of the instruments by testing the joint significance of the instruments in the first stage regression.

Empirical literature finds that human capital, as a measure of absorptive capacity, enhances technology spill-overs from FDI. In the second set of regressions, the authors test this hypothesis by including an interaction term between FDI and human capital. Given that infrastructure, as proxied by electricity consumption, is also a component of absorptive capacity, the authors include an interaction term between FDI and the electricity variable. 
The authors include the growth rate of China as a proxy for the growth of the Asian Drivers and test whether the rise of the AD's has implications for the export-led industrialisation of SSA. The authors expect the spill-over benefits from diversified productive activity to have a lagged effect on technological upgrading and thus to be the first step to upgrading export structure. The authors include a lagged term of the Herfindahl index to test this hypothesis.

\subsection{Data}

There are various ways to measure export sophistication ${ }^{4}$, all of which are essentially variations of each other. Taking into account export data considerations for SSA countries, the authors use the Hausman et al. (2007) EXPY index. The first of the two steps involves calculating the income level, or productivity level associated with each good in the export basket. This productivity level is a weighted average of the income levels of the countries that export the good. Thus, goods that are mainly exported by rich countries will have a higher productivity measure than goods that are mainly exported by poor countries. would be:

The authors assume a country to be represented by $j$ and each product by $k$. The total exports of a country $j$

$$
X_{j}=\sum_{k} x_{j k}
$$

The productivity level associated with each good $k$, PRODY $k$ would be calculated as:

$$
P R O D Y_{k}=\sum_{j} \frac{\left(x_{j k} / X_{j}\right)}{\sum_{j}\left(x_{j k} / X_{j}\right)} Y_{j}
$$

where $Y_{j}$ represents per capita GDP of each country. The weight corresponds to the revealed comparative advantage of each country in good $k$.

The productivity level of each country's export basket, EXPY $_{\mathrm{j}}$, is calculated as:

$$
E X P Y_{j}=\sum_{k}\left(\frac{x_{j k}}{X_{j}}\right) P R O D Y_{k}
$$

$E X P Y_{j}$ is a weighted average of the PRODY of each good that a country exports, the weight being the share of the particular product in total country exports.

The measure of diversification is a relative specialisation index. The relative Theil enthrophy index is chosen due to its independence of scale and population size (Parteka \& Tamberi, 2008). For the relative Theil entropy index, the authors assume there are $n$ sectors in a group of countries $m$.

If each country is represented by $j$ and each sector represented by $i$, the medium sectoral value of exports from country $j$ is:

$$
\bar{X}_{j}=\sum_{i} X_{i j} / n
$$

The share of exports in each sector, $i$, in total exports of country, $j$, is:

$$
S_{i j}=X_{i j} / \sum_{i} X_{i j}
$$

\footnotetext{
${ }^{4}$ See Xu (2000), Rodrik (2006), Lall et al. (2005), Hausman et al. (2007), Van Assche, Ganges (2008)
} 
The share of industry, I, in total world exports, is:

$$
w_{i}=\sum_{j} X_{i j} / \sum_{i} \sum_{j} X_{i j}
$$

The relative Theil index is calculated as:

$$
\text { relTheil } l_{j}=\sum_{i}^{n} S_{i j} \cdot \ln \frac{s_{i j}}{w_{i}}
$$

This is a measure of how diversified the export structure of a given country is from the rest of the group. The index ranges from 0 to an upper bound equal to $\ln (n)$. A figure closer to 0 would be indicative of a more diversified export structure relative to the rest of the group.

The data in this study are sourced from various databases. For the construction of EXPY and the relTheil index, export data are taken from the United Nations Conference on Trade and Development (UNCTAD) database. The export data are disaggregated at the SITC 3-digit level ${ }^{5}$ (rev.3) and is available from 1995, which determines the chosen estimation period. Data on GDP per capita, measured at 2000 constant US\$, PPP adjusted, is taken from the World Development Indicators (WDI) Database.

Due to missing data on exports and some of the chosen explanatory variables, only 30 of the total SubSaharan African countries could be included in the regression estimation. Although the results will not be representative of the entire region, they should provide some useful insight. Data on gross capital formation (used to calculate the capital-labour ratio), labour force, population, land area, ratio of imports to GDP, ratio of manufactured exports in total exports, foreign direct investment, and domestic credit to private sector (as a percent of GDP) are all taken from the (WDI) Database.

The preferred education variable is a measure of the proportion of the labour force with either secondary or tertiary education. This data are unfortunately not available for most countries in SSA, where data on education are scarce. The alternative measure is a primary school enrolment ratio, taken from the United Nations Educational, Scientific and Cultural Organisation (UNESCO) database. Data on foreign direct investment, as a percentage of GDP and total GDP, are taken from the UNCTAD database. The lack of data for SSA economies limits the quality of analysis and estimation on the subject of export structure upgrading ${ }^{6}$.

\section{RESULTS}

\subsection{Descriptive Statistics}

In this section, the authors present the descriptive statistics of the measures of export structure and some of the explanatory variables.

Table 1 shows that the average EXPY for the period 1995 to 2009 was 8797 . Although this figure itself is not useful, as it varies with the level of disaggregation of export data and with the specific method used to calculate EXPY, it can still be used to compare countries. An analysis of how EXPY varies over time, both within and between the group of countries, is also informative. The lower standard error on the within mean indicates that there is more variation within than between SSA countries. This is also the case when the relTheil index is used as a measure of export diversification. This implies that these countries have upgraded their export structures over the period by diversifying into a greater variety of export products as well as expanding into more value-added manufactured goods.

\footnotetext{
${ }^{5}$ More disaggregated data are more rigorous since it reflects the level of sophistication of the exports in a more accurate way.

${ }^{6}$ The authors would also like to include research and development and science education in the analysis; however, there is close to no data available for SSA countries. This could also be due to the fact that there is close to no R\&D activity in the region and science education is very low.
} 
Table 1: Summary Statistics Of EXPY And The Reltheil Index (1995-2009)

\begin{tabular}{lcccccc}
\hline Variable & & Mean & Std.Dev & Min & Max & Obs. \\
\hline EXPY & Overall & 8797.72 & 2092.02 & 0 & 16128.26 & $\mathrm{~N}=450$ \\
\hline & Between & & 1679.91 & 5487.07 & 11710.02 & $\mathrm{n}=30$ \\
& Within & & 1281.57 & 183.84 & 14687.23 & $\mathrm{~T}=15$ \\
\hline relTheil Index & Overall & 1.35 & 0.48 & 0.27 & 3.08 & $\mathrm{~N}=450$ \\
\hline & Between & & 0.45 & 0.5 & 2.42 & $\mathrm{n}=30$ \\
& Within & & 0.2 & 0.54 & 2.02 & $\mathrm{~T}=15$ \\
\hline
\end{tabular}

Source: Authors calculations

Figure 1 plots the trend of average EXPY between 1995 and 2009. Average EXPY rose steadily over the period, suggesting an improvement in export sophistication. This rise has been slow, however, and EXPY appears to have been more volatile in the period after 2000. Average EXPY rose from 8000 in 1995, reaching a peak of 9905 in 2007. This upward trend correlates with a period of increased export activity in the region. Average EXPY has been declining since 2007, which may be explained by the global economic slowdown and the fall in commodity prices.

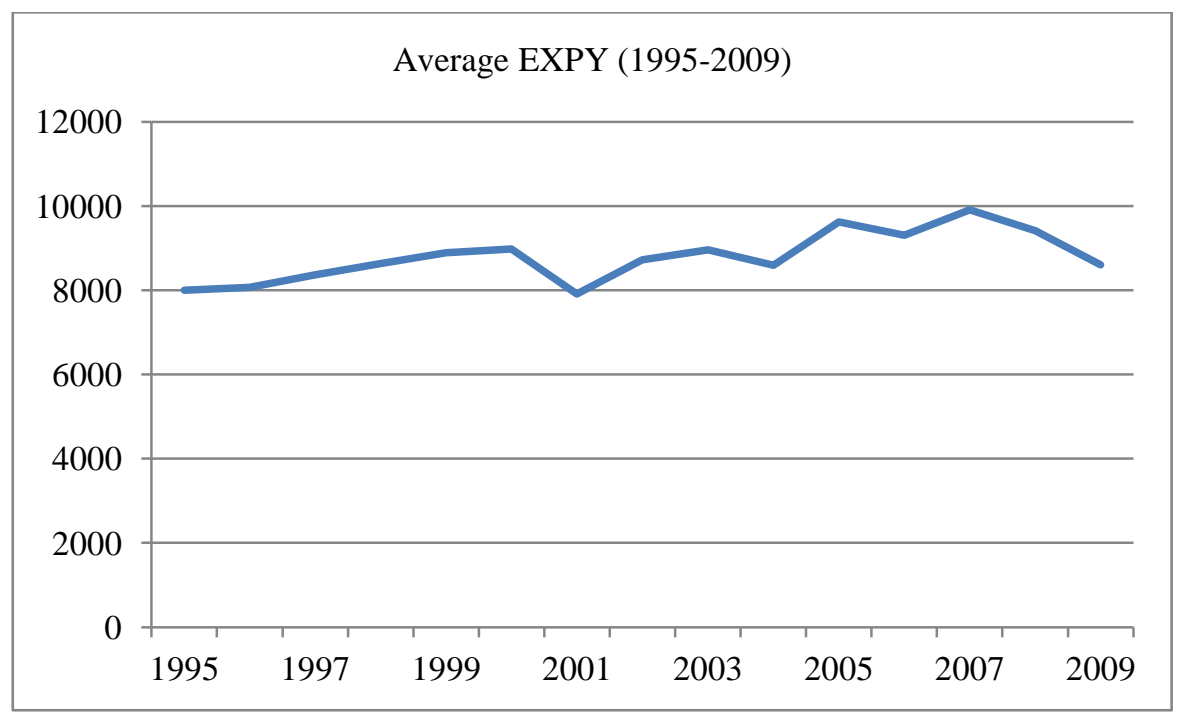

Source: Authors calculations using UNCTAD 3-digit export data

Figure 1: Average EXPY (1995-2009)

An analysis of EXPY within individual SSA countries shows that in 1995, Equatorial Guinea had the highest average EXPY value when their exports consisted primarily of wood and petroleum. Second in terms of EXPY value was Zambia, with $80 \%$ of their exports in the form of copper. Cape Verde had the third highest EXPY value in 1995, exporting mainly footwear and petroleum. In 2000, the top three EXPY countries all had major exports of petroleum. It is clear that the EXPY values of SSA countries at the time were determined primarily by commodities and not value-added products. By 2009, Comoros had the highest EXPY value with "bulk ships" as their main export. The next two countries in terms of EXPY ranking, Djibouti and South Africa, still showed reliance on commodity exports. Chad showed the biggest improvement during the period with an EXPY increasing from 4215 in 1995 to 7614 in 2009.

The drop in the relTheil index depicted in Figure 2 shows that between 1995 and 2009, SSA countries improved their performance in terms of export diversification. SSA countries are diversifying into a larger variety of products which is the first phase in export structure improvement. Once a country has gathered sufficient knowledge and technological capacity, the next phase of export structure upgrading is to move toward production of higher value added and more technology intensive products. The average relTheil index for SSA countries fell from 1.41 in 1995 to 1.26 in 2009, with a period of high volatility between 1995 and 2002. During this period, the relTheil index rose, indicating that exports were becoming less diversified. Between 2002 and 2009, however, there was a 
significant improvement in export diversification, resulting in a net decrease of the relTheil index over the total period.

South Africa, as the most developed economy in SSA, has the lowest average relTheil index score (0.503). The South African relTheil index increased over the period, reflecting a fall in export diversification. Uganda had the next lowest relTheil index score of 0.565 , which improved over the period. Chad displayed the biggest improvement in diversification with its relTheil index falling from 2.086 in 1995 to 0.966 by 2009. Comoros had the least diversified export structure, with an average relTheil index score of 2.422. Djibouti performed the worst with its index rising from 0.66 in 1995 to 1.52 by 2009.

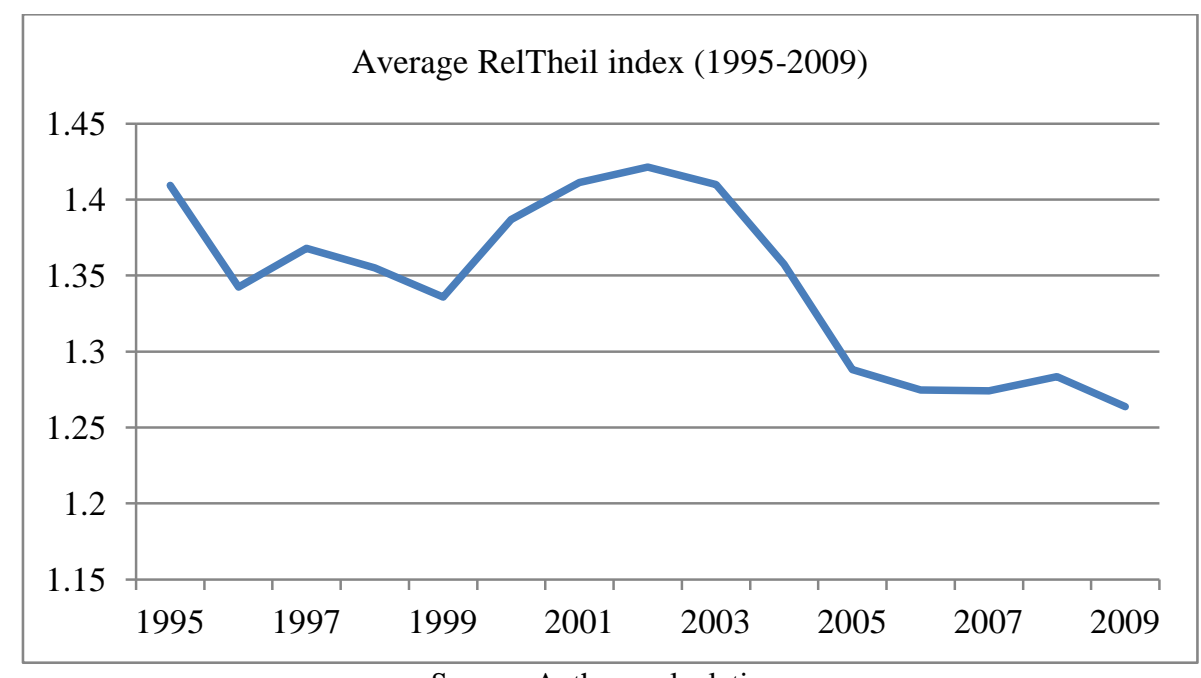

Source: Authors calculations

Figure 2: Average Reltheil Index (1995-2009)

Manufactured goods make up, on average, only $24 \%$ of total exports in the SSA. This share declined between 1995 and 2000, after which it increased toward previous 1995 levels. Over the total period, however, the average share remained almost unchanged, falling slightly from $24.5 \%$ in 1995 to $24 \%$ in 2009 . Even after excluding the major manufacture exporters in the region, such as Cape Verde, Mauritius and Lesotho, the trend remains the same.

Average FDI, as a percentage of GDP, appears to be highly volatile, ranging between $3 \%$ and $6 \%$ during the period. Equatorial Guinea, a major oil exporter in the region, had the highest FDI average of 30\% of GDP. Angola and the DRC, both major oil exporters in the region, also have high FDI to GDP ratios.

It is interesting to note that Equatorial Guinea had both the highest EXPY value and average FDI in 1995, suggesting that FDI in the country is predominantly resource based. The average manufactures' share of total exports is 3\%, making it unlikely that the FDI is based on the productive capacity of the country. This casts doubt on whether FDI in SSA has any significant impact on export structure in terms of improving the export share of manufactures. This type of FDI may have little potential knowledge and technology spill-overs for domestic economies to capture. FDI in SSA is influenced more by commodity prices than productive capacity, making it an unstable, unreliable source of technological spill-overs.

\subsection{Regression Results}

\subsubsection{Export Sophistication}

The empirical results of the pooled OLS estimation are presented in Table 2. Initially the estimation included both period and country effects, which were insignificant and therefore dropped from the estimation to preserve degrees of freedom. Column 1 presents estimates of the basic model, including only the control variables. 
Column 2 estimation accounts for possible spill-overs and productivity gains due to imports, FDI, and manufactured exports. Column 3 estimation includes electricity as a measure of infrastructure.

The coefficients on the control variables are all statistically significant and with expected signs, with the exception of population and political stability. The coefficient of population is negative and robust across all model specifications, which is not in accordance with prior expectations of a positive impact of country size on export sophistication. This may be a result of two factors. Firstly, a larger population in SSA may drain scarce government resources for key social expenditure, such as education and health care. Secondly, the drain on government resources may result in a lower quality of human capital, distorting the positive impact that a larger population has on export sophistication. The coefficient of the measure of institutional quality is statistically significant but unexpectedly negative. Weldemichael (2010) also finds a negative coefficient for institutional quality, suggesting that there are many countries with high EXPY, despite a low institutional score.

Table 2: Export Sophistication Results

\begin{tabular}{|c|c|c|c|c|}
\hline & \multicolumn{4}{|c|}{ Ln(Expy) } \\
\hline & (1)OLS & (2)OLS & (3)OLS & (4) IV \\
\hline $\ln Y$ & $0.071 * * *(0.015)$ & $0.055 * * *(0.013)$ & $0.027(0.019)$ & $0.055 * * *(0.013)$ \\
\hline $\operatorname{lnPop}$ & $-0.031 * * *(0.010)$ & $-0.060 * * *(0.012)$ & $-0.100 * * *(0.021)$ & $-0.059 * * *(0.011)$ \\
\hline lnLandp & $0.004(0.009)$ & $0.024 * *(0.010)$ & $0.022 * *(0.010)$ & $0.024 * *(0.001)$ \\
\hline Educp & $0.001 *(0.001)$ & $0.002 * *(0.001)$ & $0.002 * *(0.001)$ & $0.002 * *(0.001)$ \\
\hline Govtp & $-0.124 * * *(0.017)$ & $-0.137 * * *(0.017)$ & $-0.151 * * *(0.017)$ & $-0.137 * * *(0.017)$ \\
\hline Imp & & $-0.004 * * *(0.001)$ & $-0.005 * * *(0.001)$ & $-0.004 * * *(0.001)$ \\
\hline Fdi & & $0.005 * * *(0.001)$ & $0.005 * * *(0.001)$ & $0.005 * *(0.002)$ \\
\hline $\operatorname{lnHerf}$ & & $-0.089 * * *(0.034)$ & $-0.067 * *(0.032)$ & $-0.086 * * *(0.033)$ \\
\hline Manufexp & & $0.002 * * *(0.001)$ & $0.002 * *(0.001)$ & $0.003 * * *(0.001)$ \\
\hline $\operatorname{lnElect}$ & & & $0.033 * *(0.014)$ & \\
\hline Const & $8.894 * * *(0.235)$ & $9.520 * * *(0.230)$ & $10.384 * * *(0.415)$ & $9.512 * * *(0.227)$ \\
\hline Obs. & 317 & 314 & 314 & 313 \\
\hline R-squared & 0.20 & 0.32 & 0.34 & 0.32 \\
\hline
\end{tabular}

Note: (1) Robust standard errors in parenthesis. (2)***, **, * indicate significance levels of $1 \%, 5 \%$ and $10 \%$, respectively.

The estimation in column 2 accounts for benefits of technological spill-overs from imports and FDI and productivity gains from manufactured exports. The herfindahl index is included to test whether export diversification leads to export sophistication through the accumulation of knowledge and technical know-how. FDI has a significant and positive effect on EXPY. There may be various explanations for this outcome as imports may be dependent on a variety of factors such as domestic income, exchange rates, etc. One plausible interpretation is that excessive importation of manufactured goods, which is the regions' main import, harms local industrial development. Cheap imports may displace domestic producers, reducing local manufacturing activity. The issue of cheap textile imports from China to SSA is a well-known example. The results confirm that increased manufactured goods exportation leads to learning by exporting productivity gains that improve export sophistication.

The column 3 estimation includes electricity as a measure of infrastructure and modern production activity. The coefficient is significant and positive, implying that infrastructure is important for export sophistication. Increased electricity consumption in SSA may also be linked to an upgrading of production activity processes to those that use electrical machinery for manufacturing. GDP per capita becomes insignificant in this estimation due to its correlation with electricity consumption.

\subsubsection{Instrumental Variables (IV) Estimation}

As previously suggested, there is an endogeneity concern with including FDI in the model, as there could be bi-directional causality between FDI and export sophistication. Previous, similar empirical investigations do find evidence of endogeneity, suggesting a need to account for it in the estimation.

The authors employ a Two Stage Least Squares (2SLS) estimation technique to re-estimate the following equations simultaneously. The econometric specification is: 
$F D I_{i t}=\alpha+\beta_{0} \operatorname{Ln}\left(Z_{i t}\right)+\beta_{1}\left(\operatorname{lag} F D I_{i t}\right)+\beta_{2}\left(\operatorname{Ln} Y_{i t}\right)+\varepsilon_{i t}$

$\operatorname{Ln}\left(E X P Y_{i t}\right)=\alpha+\beta_{0} \operatorname{Ln}\left(Z_{i t}\right)+\beta_{1}\left(\widehat{F D} I_{i t}\right)+\varepsilon_{i t}$

where $Z_{i t}$ is a matrix of control variables (all other explanatory variables in column 2 specification). The lag of FDI and per capita GDP are used as instruments for FDI. The first step is to test whether FDI is endogenous, using the Durbin-Wu-Hausman test. The second step is to test the validity of the instruments.

The results of the 2SLS IV estimation are reported in Table 2, column 4. The results of the Durbin-WuHansen test of endogeneity indicate that the authors cannot reject the null hypothesis that FDI is exogenous. This result may be due to invalid instruments. The authors then test the joint significance of the instruments in the first stage regression. The results show that the instruments are jointly significantly different from zero, with a $\mathrm{p}=\mathrm{value}$ of 0.000 . The reported partial R-squared of 0.42 is sufficiently high to suggest that the instruments are significant and valid. The authors conclude that FDI is exogenous and that the OLS estimation is consistent. The results of the 2SLS estimation, as reported in column 4, are not qualitatively different from those in the OLS estimation. This result suggests that a two-way causality between FDI and export sophistication is not be observed in SSA. Generally, FDI in SSA is attracted by natural resources and not by the region's export structure, which is more commodity-based and less diversified compared to other developing countries.

\subsubsection{Export Diversification}

The variables that explain export sophistication are expected to be similar to those that explain export diversification, as both are involved in upgrading the export basket from a reliance on raw commodities toward a higher content of value-added commodities and manufactured goods. The results of the OLS diversification estimation are presented in Table 3. The first column presents the base model, column 2 includes the sources of technological spillovers, while column 3 includes electricity as a measure of infrastructure.

Table 3: Export Diversification Results

\begin{tabular}{|c|c|c|c|}
\hline & \multirow[b]{2}{*}{ (1)OLS } & \multicolumn{2}{|c|}{ Ln(relTheil) } \\
\hline & & (2)OLS & (3)OLS \\
\hline $\ln Y$ & $-0.253 * * *(0.023)$ & $-0.238 * * *(0.017)$ & $-0.201 * * *(0.022)$ \\
\hline $\ln P o p$ & $-0.071 * * *(0.017)$ & $-0.082 * * *(0.019)$ & $-0.030(0.030)$ \\
\hline lnLandp & $0.058 * * *(0.014)$ & $0.008(0.015)$ & $0.011(0.015)$ \\
\hline Educp & $-0.001(0.001)$ & $-0.001(0.001)$ & $-0.001(0.001)$ \\
\hline Govtp & $0.125 * * *(0.025)$ & $0.151 * * *(0.026)$ & $0.169 * * *(0.026)$ \\
\hline Imp & & $0.004 * * *(0.001)$ & $0.004 * * *(0.001)$ \\
\hline Fdi & & $-0.006 * * *(0.002)$ & $-0.006 * * *(0.002)$ \\
\hline Manufexp & & $-0.008 * * *(0.001)$ & $-0.007 * * *(0.001)$ \\
\hline $\operatorname{lnElect}$ & & & $-0.040 * * *(0.015)$ \\
\hline Const & $3.591 * * *(0.392)$ & $3.488 * * *(0.387)$ & $2.390 * * *(0.605)$ \\
\hline Obs. & 317 & 314 & 314 \\
\hline R-squared & 0.32 & 0.44 & 0.45 \\
\hline
\end{tabular}

Note: (1) Robust standard errors in parenthesis (2) ***, **, * indicate significance levels of $1 \%, 5 \%$ and $10 \%$, respectively.

Population is also positively ${ }^{7}$ and significantly associated with diversification, suggesting that a larger population may contribute to the expansion of the variety of output through labour-intensive production. In this case, the quality of the labour force is less important than in the case of export sophistication. The positive and significant coefficient of land per capita suggests that natural resource endowment does not benefit export diversification. This is contrary to expectations of a positive association, especially in a less-developed region in the early stages of industrialization. In a resource endowed developing country, diversification usually begins with adding value to raw materials. The result suggests that this has not been the diversification strategy in the region, where commodities are still predominantly exported in "raw form". Institutional quality has a negative impact on export diversification, similar to the result for export sophistication.

\footnotetext{
${ }^{7}$ A negative coefficient indicates a fall in the relative Theil index, which is an improvement in diversification.
} 
The column 2 estimation shows that FDI has a positive and significant effect on diversification. This suggests that there is some FDI that is not purely resource-based but contributes to the expansion of manufacturing activity. Imports are found to have a negative and significant effect on diversification. This result is robust across all model specifications. This is similar to the result obtained in the sophistication estimation and further suggests that imports have a detrimental impact on industrialization in SSA. Results in column 3 show that increased electricity consumption is associated with an improvement in export diversification.

\subsubsection{Robustness}

As discussed in the descriptive statistics section, EXPY values in SSA are not entirely reflective of the productive or technological content of the export basket. Countries with the highest EXPY values, particularly in 2000, had very high shares of petroleum exports, suggesting that major oil exporters may distort the results. The authors check the robustness of the results by excluding major oil exporters in the sample. These include Angola, Republic of Congo and Equatorial Guinea, all of which had an average share of petroleum in total exports of well above $60 \%$. The results, reported in Table 4, column 1, are strongly robust and similar to those in the initial regression estimations.

Table 4: Robustness Checks

\begin{tabular}{|c|c|c|}
\hline & $\begin{array}{c}\text { Ln(Expy) } \\
\text { (1) OLS }\end{array}$ & Ln(Nherf) \\
\hline $\ln Y$ & $0.039 * *(0.017)$ & $0.097 * * *(0.024)$ \\
\hline lnpop & $-0.060 * * *(0.012)$ & $0.157 * *(0.018)$ \\
\hline lnLandp & $0.026 * * *(0.010)$ & $-0.011(0.019)$ \\
\hline Educp & $0.002 * *(0.001)$ & $-0.004 * * *(0.001)$ \\
\hline GovtP & $-0.127 * * *(0.019)$ & $0.020(0.028)$ \\
\hline $\operatorname{Imp}$ & $-0.005 * * *(0.001)$ & $-0.008 * * *(0.002)$ \\
\hline Fdi & $0.007 * *(0.003)$ & $0.009 * * *(0.002)$ \\
\hline $\operatorname{lnHerf}$ & $-0.096 * * *(0.036)$ & \\
\hline ManufExp & $0.003 * * *(0.001)$ & $0.017 * * *(0.001)$ \\
\hline Const & $9.668 * * *(0.234)$ & $-2.001 * * *(0.428)$ \\
\hline Obs. & 289 & 314 \\
\hline R-squared & 0.32 & 0.51 \\
\hline
\end{tabular}

The authors then use an alternative measure of export diversification, the Number equivalent of the Herfindahl index ${ }^{8}$, to test the robustness of the results. The results are presented in Table 4, column 2. Whilst land per capita still has a negative impact on export diversification, it now becomes insignificant. The sign on education now becomes negative and institutional quality becomes insignificant. The impact of imports, FDI and manufactured exports is found to be robust, unchanged from the conclusion using the relative Theil index. The Rsquared of 0.51 is higher than that of the relative Theil index estimation (0.44), indicating the superiority of the Herfindahl index as a measure of export diversification.

\subsubsection{Testing Interactions, Lagged Effects, And The Impact Of The Rise Of AD's}

The authors test the interaction between FDI spill-overs and absorptive capacity, the lagged effect of a diversified export structure on export sophistication, the impact of the rise in $\mathrm{AD}$ economies, and the interaction between institutional quality and natural resource endowment. The results are presented in Table 5. Columns 1 and 2 present the results of the sophistication and diversification estimations, respectively.

\footnotetext{
${ }^{8}$ The Herfindahl index is given by $H=\sum_{i=1}^{N} S_{i}^{2}$. in which $S_{i}$ is the share of each product in total exports of each country. The number equivalent $=1 / H$. An increase in the number equivalent indicates an improvement in diversification.
} 
Table 5: Interactions, Lagged Effects And Impact Of AD's

\begin{tabular}{|l|l|l|}
\hline & Ln(Expy) & Ln(relTheil) \\
\hline & $\mathbf{1})$ OLS & $\mathbf{2}$ OLS \\
\hline $\ln Y$ & $0.042^{* * *}(0.016)$ & $-0.200 * * *(0.025)$ \\
\hline $\ln$ Pop & $-0.076^{* * *}(0.012)$ & $-0.056^{* *}(0.022)$ \\
\hline Imp & $-0.004 * * *(0.001)$ & $0.004 * *(0.001)$ \\
\hline $\ln$ Herf_1 & $-0.054 *(0.030)$ & \\
\hline Manufexp & $0.002 * *(0.002)$ & $-0.007 * * *(0.001)$ \\
\hline Finc & $0.001 * *(0.001)$ & $-0.002 * *(0.001)$ \\
\hline lnChina & $0.227 * *(0.065)$ & $-0.012(0.102)$ \\
\hline Fdi*Educp & $0.0001 * * *(0.000)$ & $-0.0001 * * *(0.000)$ \\
\hline Fdi*lnElect & $0.001 * *(0.001)$ & $-0.002 * * *(0.001)$ \\
\hline Govtp*lnLandp & $0.042 * * *(0.005)$ & $-0.042 * * *(0.008)$ \\
\hline Const & $9.410^{* * *}(0.321)$ & $2.763 * * *(0.542)$ \\
\hline Obs. & 314 & 314 \\
\hline R-squared & 0.37 & 0.44 \\
\hline
\end{tabular}

Note: (1) Robust standard errors in parenthesis. (2)***, **, * indicate respectively significance levels of $1 \%, 5 \%$ and $10 \%$ respectively

The results show that the knowledge and technological know-how gained from a diversified export structure has a lagged effect on export sophistication. This confirms that export diversification is the first step in upgrading export structure. Financial development, as a measure of absorptive capacity, is positively associated with both export sophistication and diversification. The rise of the $\mathrm{AD}$ economies has a positive impact on sophistication, but is insignificant in the diversification estimation. This suggests that the complementary effect, rather than the competitive effect, is more dominant. All interaction terms are significant. The spillover benefits from FDI are complemented by absorptive capacity to improve export structure. Institutional quality complements the effect of natural resource endowment to improve both export sophistication and diversification. Thus, natural resource abundant countries with higher quality institutions are able to benefit from their natural resources and escape the 'resource curse'.

\section{CONCLUDING REMARKS}

The aim of this paper was to discuss the motivations for upgrading the export structure of SSA countries, highlight various threats to SSA export-led industrialisation, and to estimate the determinants of these countries' export sophistication and diversification. Upgrading the SSA export structure would have a positive effect on the economic growth, human capital accumulation, savings and investment, and terms of trade of the region. The authors identified the threat of the rise of the Asian Driver economies on the export-led industrialisation of SSA. Cheap imports from the region threaten the growth of SSA exports, especially in manufactures and textiles, to third markets. Growth of these economies could therefore induce SSA countries to re-specialise in primary sector goods, slowing the industrialisation process.

The empirical results suggest that export diversification is the first step in upgrading export structure. Knowledge gained from diversifying export structure is essential for technological upgrading. Technological spillovers from foreign direct investment are important for upgrading export structure and are enhanced by greater technological absorptive capacity. It is imperative that SSA countries improve their quality of human capital and infrastructure in order to attract greater manufacture-based foreign direct investment and benefit from the resulting technological spill-overs. Imports of manufactured goods are less beneficial as a source of technological spill-overs and worsen export structure. There is evidence of learning by doing productivity gains from exporting which improve export structure. The rise of the Asian Driver economies has a favourable impact on export sophistication; however, there is now a greater need for government policy to support the manufacturing industry, with the aim of increasing exports of manufactured goods. The development of institutions in SSA is required to ensure that its high natural resource endowment contributes to the improvement of its export structure, rather than locking the region into commodity dependence. 


\section{ACKNOWLEDGEMENTS}

The authors gratefully acknowledge the support of Trade and Industrial Policy Strategies (TIPS) who provided financial support for this study by way of its small research grant initiative.

\section{AUTHOR INFORMATION}

Marcel Kohler is an academic leader and senior researcher in economics within the School of Accounting, Economics and Finance at the University of KwaZulu-Natal. His research interests lie within the field of international trade and energy economic issues. His most recent publications appeared in Energy Policy and Energy, both high impact factor Elsevier Science energy economics journals. E-mail: Kohler@ukzn.ac.za

Thembeka Khumalo is a former masters student and is currently employed as a lecturer in economics within the School of Accounting, Economics and Finance at the University of KwaZulu-Natal. Her research interests lie in the area of international economics and macroeconomic policy issues. E-mail: khumalo@ukzn.ac.za

\section{REFERENCES}

Acemoglu, D., \& Zilibotti, F. (1997). Was Prometheus Unbound by Chance? Risk, Diversification and Growth. Journal of Political Economy, 105(4): 709-751.

Adams, S. (2009). Can Foreign Direct Investment (FDI) Help to Promote Growth in Africa? African Journal of Business Management, 3(5): 178-183.

Akinlo, A. (2004). Foreign Direct Investment and Growth in Nigeria: An Empirical Investigation. Journal of Policy Modeling, 26: 627-639.

Al-Marhubi, F. (2000). Export Diversification and Growth: An Empirical Investigation. Applied Economics Letters, 7: $559-562$.

Bebczuky, R. N., \& Berrettoni, N. D. (2006). Explaining Export Diversification: An Empirical Analysis. Universidad Nacional de La Plata, Departamento de Economia, Documento de Trabajo Nro. 65.

Blalock, G., \& Gertler, P. J. (2004). Learning from exporting revisited in a less developed setting. Journal of Development Economics, 7: 397-416.

Blomstrom, M., \& Kokko, A. (2003). The Economics of Foreign Direct Investment Incentives. NBER Working Paper 9489.

Borensztein, E. J., De Gregorio, J. W., \& Lee, J. W. (1998). How Does FDI Effect Economic Growth. Journal of International Economics, 45(1): 115-135.

Cabral, C., \& Viega, P. (2010). Determinants of Export Diversification and Sophistication in Sub-Saharan Africa. NBER Project on African Development.

Carkovic, M., \& Levine, R. (2002). Does Foreign Direct Investment Accelerate Growth? In Moran, H. T., Graham, E., Blomstrom, M. (eds.). Does FDI Promote development? Institute for International Economics, Washington DC.

Coe, D. T., Helpman, E., \& Hoffmaister, A. W. (1997). North-South R\&D Spillovers. Economic Journal, 107: 134149.

Collier, P., \& Goderis, B. (2007). Commodity Prices, Growth, and the Natural Resource Curse: Reconciling a Conundrum. CSAE Working Paper Series 2007-15.

De Long, J. B., \& Williamson, J. G. (1994). Natural Resources and Convergence in the Nineteenth and Twentieth Century's. Harvard University.

De Mello, L. R. (1997). Foreign Direct Investment in Developing Countries and Growth: A Selective Survey. Journal of Development Studies, 34(1): 1-34.

De Mello, L. R. (1999). Foreign Direct Investment-Led Growth: Evidence from Time Series and Panel Data. Oxford Economic Papers, 51: 133-151.

DFID. (2005). The Effect of China's and India's Growth and Trade Liberalisation on Poverty in Africa. DFID, Final Report, Readings DCP 70.

Dixit, A., \& Norman, V. (1980). Theory of International Trade: A Dual, general Equilibrium Approach. Cambridge University Press, Cambridge.

Dunning, J. H., \& Narula, R. (2004). Multinational and Industrial Competitiveness: A New Agenda. Edward Elgar: 
Cheltenham.

Dutt, A. K. (1997). The Pattern of Foreign Direct Investment and Economic Growth. World Development, 25(11): 1925-1936.

Eichengreen, B. R. Y., \& Tong, H. (2004). The Impact of China on Exports of other Asian Countries. NBER Working Paper No.10768.

Fu, X., Mingyong, L., Xuan, J., \& Zhu, S. (2009). What Drives Export Sophistication? University of Oxford, SLPTMD Working Paper series No.033.

Fry, M. J. (1993). FDI in A Macroeconomic Framework: Finance, Efficiency, Incentives and Distortions. World Bank, Policy Research Working Paper No. 1141.

Greenway, D., Foster, N., \& Falvey, R. (2007). Economics Letters, 97:230-234.

Gylfason, T., \& Zoega, G. (2006). Natural Resources and Economic Growth: The Role of Investment. The World Economy, 1091-115.

Habiyaremye, A., \& Ziesemer, T. (2006). Absorptive Capacity and Export Diversification in SSA Countries. United Nations University MESR Working Paper No. 2006-030.

Haddad, M., \& Harrison, A. (1993). Are There Positive Spillovers from Direct Foreign Investment? Evidence from Panel Data for Morocco. Journal for Development Economics, 42: 51-74.

Harrigan, J., \& Zakrajsek, E. (2000). Factor Supplies and Specialisation in the World Economy. NBER Working Paper No. 7848.

Harvey, D. I., Kellard, N. M., Madsen, J. B., \& Wohar, M. E. (2010). Review of Economics and Statistics, 92(2): 367-377.

Hausmann, R., Hwang, J., \& Rodrik, D. (2007). What You Export Matters. Journal of Economic Growth, 12: 1-25.

Helpman, E., \& Krugman, P. (1985). Market Structure and Foreign Trade. The MIT Press, Cambridge.

Hermes, N., \& Lensink, R. (2003). Foreign Direct Investment, Financial Development and Economic Growth. Journal of Development studies, 40(1): 142-153.

Herzer, D., \& Nowak-Lehmann, F. (2006). What Does Export Diversification Do for Growth? An Econometric Analysis. Applied economics, 38(15): 1825-1838.

Hummels, D., \& Klenow, J. P. (2005). The Variety and Quality of a Nations Exports. The American Economic review, 95(3): 704-723.

Jenkins, R., \& Peters, E. D. (2006). The Impact of China on Latin America and The Caribbean. DFID China Office.

Kaplinsky, R. (2004). Spreading the Gains from Globalisation: What Can Be learned from Value Chain Analysis? Problems of Economic Transition, 47(2): 74-115.

Kaplinsky, R. (2008). What does the Rise of China Do for Industrialisation in Sub-Saharan Africa. Review of African Political Economy, 35(115): 7-22.

Kaplinsky, R., \& Morris, M. (2008). Do the Asian Drivers Undermine Export-oriented Industrialisation in SSA? World Development, 36(2): 254-273.

Keller, W. (1996). Absorptive Capacity: On the Creation and acquisition of Technology in Development. Journal of Development Economics, 49: 119-227.

Krugman, P. (1980). Scale Economics, Product Differentiation, and the Pattern of Trade. American Economic Review, 70: 950-959.

Lall, S. (2000). The Technological Structure and Performance of Developing Country Manufactured Exports: 19851998. Oxford Development Studies, 28(3): 337-369.

Lall, S., \& Pietrobelli, C. (2005). National Technology Systems in Sub-Saharan Africa. International Journal of Technology and Globalisation, 1(3): 311-342.

Lall, S., \& Narula, J. (2004). FDI and Its Role in Economic Development: Do We Need a New Agenda. MERITInfonomics Research Memorandum Series 2004-019.

Lall, S., Weiss, J., \& Zhang, J. K. (2006). The Sophistication of Exports: A New Trade Measure. World Development, 34(2): 222-237.

Le Vu, M., \& Suruga, T. (2005). Foreign Direct Investment, Public Expenditure and Economic Growth: An Empirical Evidence for the period 1970-2001. Applied Economic Literature, 12: 45-49.

Li, X., \& Liu, X. (2005). Foreign Direct Investment and Economic Growth: An Increasingly Endogenous Relationship. World Development, 33(3): 393-407.

Matsuyama, K. (1992). Agricultural Productivity, Comparative Advantage and Economic Growth. Journal of Economic Theory, 58:317-334.

Makki, S. (2004). Impact of foreign Direct Investment and Trade on Economic Growth. American Journal of 
Agriculture, 89(3): 795-801.

Mengistae, C., \& Pattillo, C. (2004). Export Orientation and Productivity in Sub-Saharan Africa. IMF Staff Papers, 51(2): 327-353.

Morris, M., \& Einhorn, G. (2008). Globalisation, Welfare, and Competitiveness: The Impacts of Chinese Imports on the South African Clothing and Textile Industry. Competition and Change. 12(4): 355-376.

Morrissey, O., \& Ackah, C. (2005). Trade Policy and Performance in Sub-Saharan Africa Since the 1980's. CREDIT Research Paper No. 05/13.

Mytelka, L. K. (1985). Stimulating Effective Technology Transfer: The Case of Textiles in Africa, in Rosenberg, N., Frischtak, C. (eds.), International Technology Transfer, Praeger: New York.

Narula, R., \& Marin, A. (2003). FDI Spillovers, Absorptive Capacities, and Human Capital Development: Evidence from Argentina. MERIT Research Memorandum 2003-16.

Narula, R. (2004). Understanding Absorptive Capacity in an "Innovation System" Context: Consequences for economic and Employment Growth, MERIT-Infonomics Research Memorandum Series No.3.

Ndikumana, L., \& Verick, S. (2008). The Linkages Between FDI and Domestic Investment: Unravelling the Developmental Impact of foreign Direct Investment in Sub-Saharan Africa. IZA Working Paper No. 3296.

Noorbukhsh, F., Paloni, A., \& Youssef, A. (2001). Human Capital and FDI inflows to Developing Countries: New Empirical Evidence. World Development, 29(9): 1593-1610.

Page, J. (2010). Should Africa Industrialise? The Brookings Institution.

Palley, T. (2003). Export-Led Growth: Evidence of Developing Country Crowding-Out. In Arestis, P., Baddeley, M., McComber, J. (eds.). Globalisation. Regionalism, and economic Activity. Edward Elgar, Northampton.

Papyrakis, E., \& Gerlagh, R. (2003). The Resource Curse Hypothesis and its Transmission Channels. Journal of Comparative Economics, 32:181-193.

Parteka, A., \& Tamberi, M. (2008). Determinants of Export Diversification: An Empirical Investigation. Politecnica delle Marche, Dipartimento di Economia Universita, Quaderno di Ricerca (Working Paper) No. 327.

Qureshi, M. S., \& Wan, G. (2006). Trade Potential for China and India: Threat or Opportunity.

Rodrik, D. (1998). Trade Policy and Performance in Sub-Saharan Africa. Expert Group on Development Issues. Harvard University.

Rodrik, D. (2006). What is So Special about China's Exports. China and the World Economy, 14(5): 1-19.

Romer, P. (1990). Endogenous Technical Change. Journal of Political Economy, 98: 71-102.

Rosser, A. (2006). Escaping the Resource Curse. New Political Economy, 11(4): 557-570.

Sachs, D. J., \& Warner, A. M. (1995). Natural Resource Abundance and Economic Growth. NBER Working Paper Series 5398: 1-47.

Sachs, D. J., \& Warner, A. M. (2001). Natural Resources and Economic Development: The Curse of the Natural Resources. European Economic Review, 45: 827-838.

Schott, P. (2008). The Relative Sophistication of Chinese Exports. Economic Policy, 1: 5-49.

Seck, A. (2009). International Technology Diffusion: Explaining the Spillover Benefits to African and other Developing Countries.

Sekkat, K., \& Veganzones-Varoudakis, M. (2007). Openess, Investment Climate and FDI in Developing Countries. Review of Development Economics, 11(4): 607-620.

Shafaeddin, S. M. (2002). The Impact of China's Accession to WTO on The Export of Developing Countries. UNCTAD Discussion Papers No. 160.

Singer, H. W. (1950). The Distribution of Trade Between Investing and Borrowing Countries. American Economic Review, 40: 473-485.

Stijns, J. (2005). Natural Resource Abundance and Economic Growth Revisited. Resources Policy, 30: 107-130.

Sylwester, K. (2005). Foreign Direct Investment, Growth and Income Inequality in Less Developed Countries. International Review of Applied Economics, 19(3): 289-300.

Van Assche, A., \& Gangnes, B. (2008). Electronics Production Upgrading: Is China Exceptional? University of Hawaii at Manoa, Department of Economics, Working Papers 200722.

Van Biesebroeck, J. (2005). Exporting Raises Productivity in Sub-Saharan Manufacturing Firms. Journal of International Economics, 67: 373-391.

Wang, Z., \& Wei, J. S. (2007). The Rising Sophistication of China's Exports: Assessing the Roles of Processing Trade, Foreign Invested Firms, Human Capital, and Government Policies. Working Paper for NBER conference on China's Growing Role in World Trade.

Worz, J. (2005). Skill Intensity in Foreign Trade and Economic Growth. Empirica, 32: 117-144. 
Woerz, J., \& Stehrer, R. (2009). Industrial Diversity, Trade Patterns, and Productivity Convergence. Review of Development Economics, 13(2): 356-372.

Weldemichael, E, O. (2010). Determinants of Export Sophistication. University of Melbourne.

Xu, B. (2000). Multinational Enterprises, Technology Diffusion and Host Country Productivity Growth. Journal of Development Economics, 62: 447-93. 